\title{
Cloning and characterization of genes expressed during gametogenesis of female and male mice
}

\author{
D. M. López-Alañón and J. del Mazo* \\ Centro de Investigaciones Biológicas, Velázquez 144, 28006-Madrid, Spain
}

\begin{abstract}
Isolation and initial characterization of clones from a mouse fetal ovary cDNA library are reported. In mammals, the development of female gametogenesis, including the prophase of the first meiotic division, begins in the fetus. A parallel conserved process occurs in males, from puberty onwards. We cloned cDNAs preferentially expressed in both sexes during gametogenesis considering both the meiotic programme and the non-germ cells participating in the developmental regulation of gametogenesis. From 183 clones that showed positive hybridization with adult testis and negligible hybridization with somatic probes, 32 clones were selected. After partial sequencing, 16 were found to correspond to known genes that are expressed during other programmes of differentiation and development. Sixteen clones represent novel sequences. The accumulation of corresponding transcripts was analysed by developmental northern blots during spermatogenesis, and genes expressed during gametogenesis were characterized together with others showing pleiotropic expression in different tissues. Additional specific, gametic transcripts were also detected.
\end{abstract}

\section{Introduction}

Differential screening of cDNA libraries has been carried out to isolate genes expressed in a defined developmental process and at a specific stage (Höög, 1991; Nedivi et al, 1993). In this context, and consistent with the goals of the Human Genome Programme (Adams et al., 1991, 1993), different tissues and systems are being assessed to isolate specific genes involved in the gene regulation of the various developmental stages of tissues and organisms. This approach contributes potential new tags for genome mapping and the characterization of unknown proteins and associated functions.

Gametogenesis is a developmental process that involves cascades of regulatory gene expression. In mammals, as a result of terminal differentiation, the gamete is the product of differentiation events in germ cells, including meiosis, and regulatory interaction with somatic components of the gonads, coordinated by endocrine signals. The origin of gametocytes is common to both sexes: they are derived from primordial germ cells after they reach and colonize the genital ridges, in mice, 11 days after coitus (Mintz and Russell, 1957).

In mammalian fetuses, the programme of gonad sex-specific differentiation is followed by a defined pathway of entry into meiosis to generate oocytes in females and prospermatogonia in males. The timing of meiosis and the development of gametogenesis is different between the sexes. In females, germ cell development is characterized by early onset of the meiotic prophase, which starts in the mouse fetus 13 days after coitus, and progresses under partial synchrony until the dictyotene stage at birth. In contrast, spermatogenesis is a continuous

*Correspondence.

Received 19 October 1994. process, in which the onset of the first meiosis occurs at puberty and continues throughout adult life. In addition, the development of gametogenesis is controlled by complex mechanisms of endocrine, paracrine and autocrine regulation (Pescovitz et al., 1994), which also includes active cell to cell signalling, which can modulate the process both in oogenesis and spermatogenesis. Sertoli cells in the testes (Djakiew and Dym, 1988) and granulosa cells in the ovaries (Eppig, 1991) could play a similar role in such regulation. Thus, the same or related genes could be expressed during the corresponding stages of development in both sexes. In addition to isolating genes involved in the regulation of oocyte progression in the mammalian fetus, interest in characterizing genes expressed preferentially, both in fetal ovaries and adult testes, is based on (i) genes expressed in the same process, e.g. meiosis; (ii) genes involved in regulation by interaction between somatic and germ cells; and (iii) genes involved in mechanisms of terminal differentiation.

In female mouse fetuses, about $75 \%$ of the oocytes are at the pachytene stage 16 days after coitus (Speed, 1982). Transcripts corresponding to products involved in the same functions and expressed at this stage, in which a high rate of transcription occurs (Kierszenbaum and Tres, 1974; Hecht, 1986), should be present in adult testes, in which about $30 \%$ of the seminiferous tubule cells are also at the pachytene stage (Bellvé et al., 1977). Thus, to identify clones corresponding to transcripts present in the development of male and female gametogenesis, including those controlling meiosis, a cDNA library has been generated from fetal ovaries at 16 days after coitus. A two-step differential screening method has been developed, using as probes single strand $\mathrm{cDNAs}$ reverse transcribed from somatic tissue mRNAs versus testis mRNAs. After this double differential screening, 32 clones were isolated, $50 \%$ of which represented 
genes not previously described. Developmental expression analysis during gametogenesis of novel genes shows possible roles for these genes expressed during gametogenesis.

\section{Materials and Methods}

\section{Construction of a fetal ovary cDNA library}

Female embryos were selected from Swiss mice at 16 days of pregnancy and, after dissection, 300 ovaries from those embryos were collected. Total RNA was purified from the ovaries as described by Chomczynski and Sacchi (1987). Poly $(\mathrm{A})+$ RNA was selected using biotinylated oligo(dT) as primer, and captured with streptavidin coupled to paramagnetic particles (López-Fernández and del Mazo, 1993) in a magnetic separation stand (Promega, Madison). The cDNA was synthesized from $5 \mu \mathrm{g}$ of ovary poly $(\mathrm{A})+\mathrm{RNA}$, using an oligo $(\mathrm{dT})_{12-10}$ as primer having a Xhol site at the $3^{\prime}$ end. Fractioning of double-stranded, $\left[{ }^{32} \mathrm{P}\right]$ cDNA, on $3.5 \%$ acrylamide gels, indicated that cDNA ranged from 900 to 4500 base pairs and most were about 1300 base pairs. Directional cDNA inserts were generated into $\lambda$ uni-Zap XR vector (Stratagene, La Jolla), after ligation of EcoRI linkers and digestion with EcoRI and Xhol. Ligated DNA was packaged in vitro using a commercial extract from Stratagene.

\section{Selection of $c D N A$ clones by differential screening}

After infection of SURE cells (Stratagene) by phages, approximately 10000 plaques were screened at a density of $1000 \mathrm{pfu}$ per nitrocellulose filter (Schleicher and Schuell, Dassel). The probes of single-stranded cDNA used in the differential screening were obtained from $5 \mu \mathrm{g}$ of an equivalent mixture of poly (A) + RNAs prepared from kidney, muscle, intestine and liver from embryos at day 16 after coitus, or alternatively from $5 \mu \mathrm{g}$ of poly $(\mathrm{A})+\mathrm{RNAs}$ prepared from adult testes. The single-stranded cDNAs were synthesized by starting the reaction with an oligo $(\mathrm{dT})_{12-16}$ primer by adding AMV reverse transcriptase (Promega, Madison). The single stranded cDNAs were labelled by incorporation of $\left[\alpha^{-32} \mathrm{P}\right] \mathrm{dCTP}$ (3000 Ci mmol $]^{-1}$ ) in the reverse transcription reaction. The differential screening was performed by hybridization at $42^{\circ} \mathrm{C}$ for $72 \mathrm{~h}$ on duplicate filters with somatic versus testis probes in: $50 \%(\mathrm{w} / \mathrm{v})$ formamide, $0.25 \%(\mathrm{w} / \mathrm{v})$ SDS, $5 \times$ SSC $\left(1 \times\right.$ SSC is $150 \mathrm{mmol} \mathrm{l}^{-1} \mathrm{NaCl} / 15 \mathrm{mmol}$ sodium citrate $\mathrm{I}^{-1}, \mathrm{pH} \mathrm{7.0)}, 5 \times$ Denhardt's solution $(1 \times$ Denhardt's solution is $0.02 \%(\mathrm{w} / \mathrm{v})$ bovine serum albumin $/ 0.02 \%(\mathrm{v} / \mathrm{v})$ Ficoll $/ 0.02 \%(\mathrm{w} / \mathrm{v})$ polyvinylpyrrolidone) and $100 \mu \mathrm{g}$ of denatured salmon spermatozoa DNA $\mathrm{ml}^{-1}$, using $10^{6}$ c.p.m. probe $\mathrm{ml}^{-1}$. The filters were washed at $65^{\circ} \mathrm{C}$ for $30 \mathrm{~min}$ in $0.1 \times \mathrm{SSC}, \quad 0.1 \%(\mathrm{w} / \mathrm{v})$ SDS (Sambrook et al., 1989). The autoradiographic film was developed after exposure for 3 days. The pfus that exhibited positive hybridization with testis probes and null or negligible hybridization with somatic probe single stranded cDNAs were selected and suspended in $1 \mathrm{ml}$ $\mathrm{SM}$ buffer $\left(0.1 \mathrm{~mol} \mathrm{NaCl} \mathrm{l}^{-1}, 10 \mathrm{mmol} \mathrm{MgSO}_{4} \mathrm{l}^{-1}, 50 \mathrm{mmol}\right.$ Tris- $\mathrm{HCl} \mathrm{l} l^{-1} \mathrm{pH} 7.5$, gelatin $0.01 \% \mathrm{w} / \mathrm{v}$ ) with $20 \mu \mathrm{l}$ chloroform (Sambrook et al., 1989). (a)

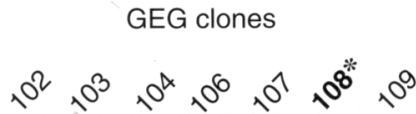

$\mathrm{kb}$

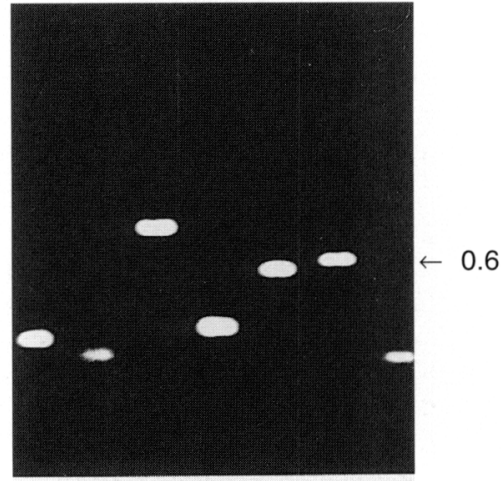

(b)

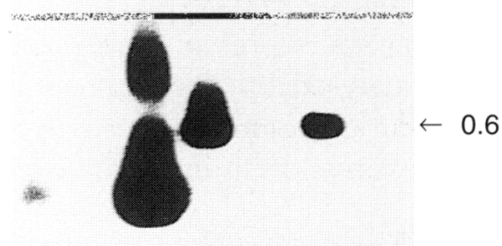

(c)

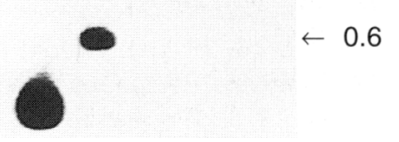

Fig. 1. Example of the second differential screening using PCR amplified cDNA inserts. (a) Ethidium bromide staining of PCR products after agarose gel electrophoresis. (b) Southern blot of PCR products from gel (a), after hybridization using single strand DNAs from adult testis RNA as probe. (c) Blot from a duplicate gel hybridized with single-stranded cDNAs from somatic RNA. A differential signal is observed in the clone GEG-108.

\section{Second screening of clones}

The second screening was performed by Southern blot analysis (Sambrook et al., 1989) of PCR-amplified insert DNAs from initially selected clones. For this, 20-base primers corresponding to the opposite side of the cDNA flanking the cloning site in the vector were synthesized: primer (5'-TGTAAAACGACGGCCAGTGA-3') and reverse primer $\left(5^{\prime}\right.$-TGACCATGATTACGCCAAGC- $\left.3^{\prime}\right)$. For the polymerase chain reaction (PCR) 25 pmol of each primer and reverse primer 
Table 1. Similarities of the clones of mouse gametogenesis expressed genes with sequences in the EMBL database

\begin{tabular}{|c|c|c|c|c|}
\hline GEG clone no. & $\begin{array}{l}\text { Putative identification } \\
\text { (species) }\end{array}$ & $\begin{array}{c}\text { Per cent similarity } \\
5^{\prime} \text { end } \\
\text { (base pairs) }\end{array}$ & $\begin{array}{c}\text { Per cent similarity } \\
3^{\prime} \text { end } \\
\text { (base pairs) }\end{array}$ & $\begin{array}{c}\text { EMBL } \\
\text { accession no. }\end{array}$ \\
\hline GEG-98 & surf-3 (M) & $92 \%(172)$ & $86 \%(148)$ & M20741 \\
\hline GEG-25 & Collagen (VI), $\alpha 2(\mathrm{M})$ & $98 \%(149)$ & $98 \%(205)$ & $\times 62332$ \\
\hline GEG-61 & Pyruvate kinase-M1, M2 (R) & $87 \%(132)$ & $\leq 40 \%$ & M24359 \\
\hline GEG-139 & Insulin-like growth factor II (M) & $95 \%(160)$ & $81 \%(118)$ & M36332 \\
\hline GEG-72 & Laminin B2 (M) & $96 \% \quad(97)$ & $98 \%(193)$ & J03484 \\
\hline GEG-164 & $\mathrm{Na}, \mathrm{K}$-ATPase, $\alpha 1(\mathrm{H})$ & $\leq 40 \%$ & $85 \%(148)$ & $\times 04297$ \\
\hline GEG-178 & c-jun $(\mathrm{M})$ & $92 \%(148)$ & $90 \%(164)$ & J04115 \\
\hline GEG-89 & Histone H3.3, pseudogen (M) & $93 \%(114)$ & $85 \%(145)$ & M18678 \\
\hline GEG-92 & Histone $\mathrm{H} 3.3$, pseudogen (M) & $78 \% \quad(75)$ & $91 \%(180)$ & M18678 \\
\hline GEG-17 & Mitochondrial genome (M) & $93 \%(127)$ & $94 \%(121)$ & Voo711 \\
\hline GEG-102 & Mitochondrial genome (M) & $97 \%(111)$ & $90 \%(122)$ & Voo711 \\
\hline GEG-70 & Globin, $\alpha(\mathrm{M})$ & $85 \%(130)$ & $89 \%(209)$ & Voo714 \\
\hline GEG-90 & Globin, $\alpha(\mathrm{M})$ & $98 \% \quad(88)$ & $85 \% \quad(80)$ & Voo714 \\
\hline GEG-104 & Globin, $\alpha(\mathrm{M})$ & $\leq 40 \%$ & $95 \%(173)$ & V00714 \\
\hline GEG-146 & Ubiquitin (M) & $98 \%(144)$ & $98 \%(180)$ & $\times 51703$ \\
\hline GEG-159 & Ubiquitin (M) & $85 \% \quad(76)$ & $90 \%(171)$ & $\times 51703$ \\
\hline
\end{tabular}

GEG: gametogenesis expressed gene; M: mouse; R: rat; H: human.

(Saiki $e t$ al., 1985) were combined with the following reagents in a final volume of $100 \mu \mathrm{l}: 10 \mu \mathrm{l}$ of the phage suspension, $0.2 \mathrm{mmol} \mathrm{l}^{-1}$ of each deoxynucleotide, PCR buffer $(50 \mathrm{mmol}$ $\mathrm{KCl} \mathrm{l} \mathrm{l}^{-1}, 10 \mathrm{mmol}$ Tris $-\mathrm{HCl} \mathrm{l} \mathrm{l}^{-1}, \mathrm{pH} 8.8$ at $25^{\circ} \mathrm{C}, 1.5 \mathrm{mmol}$ $\mathrm{MgCl}_{2} \mathrm{I}^{-1}$ and $1 \%(\mathrm{w} / \mathrm{v})$ Triton X-100) and $2.5 \mathrm{U}$ of TaqDNA polymerase (Promega). After 35 cycles of PCR, the lengths of the cDNAs amplified were analysed by electrophoresis in a $1 \%$ $(w / v)$ agarose gel in duplicate. The gels were blotted to nylon filters and the blots hybridized with the same first single stranded cDNA probes from the somatic tissues and adult testis, and under the same conditions as in the first screening. The cDNA clones that showed strong hybridization with adult testis CDNA and null or negligible hybridization with somatic cDNA probes were finally selected (Fig. 1).

In vivo excision of pBluescript containing the $C D N A$ inserts

The cloned inserts contained within the $\lambda$ uni-ZAP XR vector were excised in vivo following the commercial protocol (Stratagene). The rescued phagemid was plated on Luria Bertani (LB)/Ampicillin plates and incubated overnight at $37^{\circ} \mathrm{C}$. The colonies were isolated, incubated in LB-Ampicillin media and stored at $-80^{\circ} \mathrm{C}$ with $50 \%(\mathrm{v} / \mathrm{v})$ glycerol.

\section{DNA sequencing}

Dideoxy-terminator sequencing reactions were performed with $\left[\alpha-{ }^{35}\right.$ S $] \mathrm{dATP}$ and using both primers (to sequence the $3^{\prime}$ end) and reverse primers (to sequence the $5^{\prime}$ end) synthesized for the DNA amplification of the inserts, following the instructions of the T7-Sequencing Kit purchased from Pharmacia Biotech (Uppsala).

\section{Northern blot analysis}

Total RNA was isolated from $100 \mathrm{mg}$ of tissues using the acid phenol-guanidinium method (Chomczynski and Sacchi, 1987). Human testis RNA was obtained from orchidectomy biopsies from patients with normal spermatogenesis development. The informed consent of the patients and approval of the local ethical committee were obtained. The RNA was separated by electrophoresis in $1 \%(\mathrm{w} / \mathrm{v})$ agarose with $17 \%$ formaldehyde $(\mathrm{v} / \mathrm{v})$ under denaturing conditions and transferred onto nylon membranes by a vacuum blotter. The gametogenesis expressed genes and $\beta$-actin-containing plasmids were labelled with $\left[\alpha-{ }^{32} \mathrm{P}\right] \mathrm{dCTP}$ by random hexanucleotide priming and hybridized to the membranes at $42^{\circ} \mathrm{C}$ overnight. Blots were washed twice at room temperature in $2 \times \mathrm{SSC} / 0.1 \%(\mathrm{w} / \mathrm{v}) \mathrm{SDS}$ and twice at $55^{\circ} \mathrm{C}$ in $0.1 \times \mathrm{SSC} / 0.1 \%(\mathrm{w} / \mathrm{v}) \mathrm{SDS}$. Autoradiographs were obtained after exposure of blots to Kodak-XAR film with intensifying screens.

\section{Results}

\section{Analysis and isolation of $c D N A$ clones}

The cDNA library contained $5 \times 10^{5}$ primary plaques and was amplified to a titre of $3 \times 10^{9} \mathrm{pfu} \mathrm{ml}^{-1}$. The library was evaluated by screening lifts from 20000 plated clones and scoring positive clones on films after hybridization with a $\beta$-actin probe. The frequency of actin cDNA clones was $0.37 \%$. This result is similar to that obtained in a similar fetal ovary cDNA library from day 17 after coitus $(0.25 \%)$, but different from an adult testis cDNA library $(0.07 \%$; unpublished data). Consequently, the results are internally coherent and, as they are in the range of actin-hybridizing clones found in cDNA 
Table 2. Developmental gene expression for novel gametogenesis expressed genes by northern analysis

\begin{tabular}{|c|c|c|c|}
\hline $\begin{array}{l}\text { GEG clone } \\
\text { number }\end{array}$ & $\begin{array}{l}\text { Transcript size } \\
\text { detected in } \\
\text { adult testis }(\mathrm{kb})\end{array}$ & $\begin{array}{l}\text { Level of expression } \\
\text { during testis } \\
\text { development from } \\
\text { day } 6 \text { to adult }\end{array}$ & $\begin{array}{c}\text { Transcript size } \\
\text { detected in } \\
\text { somatic tissues }(k b)\end{array}$ \\
\hline \multirow[t]{2}{*}{ GEG-60 } & 1.0 & + & None detected \\
\hline & 1.9 & + & 1.9 \\
\hline \multirow[t]{2}{*}{ GEG-65 } & 2.4 & $=$ & 2.4 \\
\hline & 6.0 & $=$ & 6.0 \\
\hline \multirow[t]{4}{*}{ GEG-68 } & 1.6 & + & 1.6 \\
\hline & 1.9 & + & 1.9 \\
\hline & 3.0 & + & None detected \\
\hline & 4.2 & $=$ & 4.2 \\
\hline GEG-91 & 5.0 & $=$ & 5.0 \\
\hline \multirow[t]{3}{*}{ GEG-93 } & 2.0 & $=$ & 2.0 \\
\hline & 2.4 & $=$ & 2.4 \\
\hline & 5.2 & + & None detected \\
\hline \multirow[t]{2}{*}{ GEG-97 } & 1.9 & $=$ & 1.9 (none detected in brain) \\
\hline & 5.3 & - & $\begin{array}{l}5.3 \text { (high level in brain and } \\
\text { none detected in kidney) }\end{array}$ \\
\hline GEG-108 & 7.0 & $=$ & None detected \\
\hline \multirow[t]{2}{*}{ GEG-12I } & 2.4 & $=$ & 2.4 \\
\hline & 4.8 & - & 4.8 \\
\hline \multirow[t]{3}{*}{ GEG-123 } & 1.2 & + & None detected \\
\hline & 1.9 & $=$ & 1.9 (very low expression) \\
\hline & 5.0 & - & 5.0 \\
\hline \multirow[t]{3}{*}{ GEG-136 } & 1.8 & $=$ & 1.8 \\
\hline & 3.8 & + & None detected \\
\hline & 4.7 & - & 4.7 \\
\hline \multirow[t]{2}{*}{ GEG-152 } & 2.4 & $=$ & 2.4 (very low expression) \\
\hline & 6.0 & + & 6.0 \\
\hline \multirow[t]{2}{*}{ GEG-154 } & $\begin{array}{l}3.0 \text { (only detected } \\
\text { in day } 22 \text { and adult) }\end{array}$ & + & None detected \\
\hline & 4.2 & + & None detected \\
\hline \multirow[t]{2}{*}{ GEG-168 } & 2.0 & $\begin{array}{c}+\underset{\text { at dayimum }}{14)} \\
\text { at }\end{array}$ & None detected \\
\hline & 5.4 & $=$ & 5.4 (very low expression) \\
\hline
\end{tabular}

The level of transcript accumulation during testis development is represented as $(-)$ : decreasing; $(=)$ : constant; or $(+)$ : increasing. GEG: gametogenesis expressed gene.

libraries from different mammalian tissues (Ausubel et al., 1990), could be considered in the evaluation of similar libraries. The proportion of recombinants was $70 \%$; both after in vivo excision of a sample of the cDNA library and scoring the percentage of white/blue colonies plated on X-gal/IPTG medium.

Approximately 10000 clones were distributed onto 10 plates. The abundantly expressed cDNA clones (Sambrook et al., 1989) were marked by hybridizing duplicate filters with a mixture of single-stranded cDNA prepared from a mix of fetal kidney, muscle liver and intestine RNAs or with single stranded cDNA prepared from adult testes. From this screening, 183 clones that were positive with testis and negative with somatic probes were selected.

These cDNA clones were rescreened after PCR amplification, blotted on nylon filters and screened by somatic versus testis probes. The size of the $183 \mathrm{cDNA}$ cloned inserts ranged from 300 to 3000 base pairs, with an average of 1600 base pairs. After this second screening, 32 clones showed strong hybridization with testis cDNA and negligible hybridization with somatic cDNA probes (Fig. 1).

\section{Characterization of GEG clones}

At least $150-200$ base pairs of high quality sequence data from both $3^{\prime}$ and $5^{\prime}$ ends, corresponding to the partial sequencing of the 32 gametogenesis expressed gene cDNAs were compared to the GenBank and EMBL databanks using the FASTA program (Pearson, 1990). Fifty per cent of the gametogenesis expressed gene clones revealed no significant similarities (less than $85 \%$, sequencing more than 300 base pairs for each clone) to any sequence included in both databases. Therefore, these clones could be novel mouse cDNA sequences. Sixteen of these mouse cDNA clones shared similarities with genes previously characterized in mice, humans or rats (Table 1). Redundancy appeared in some gametogenesis expressed gene clones including histone H3.3 (GEG-89, 92), 


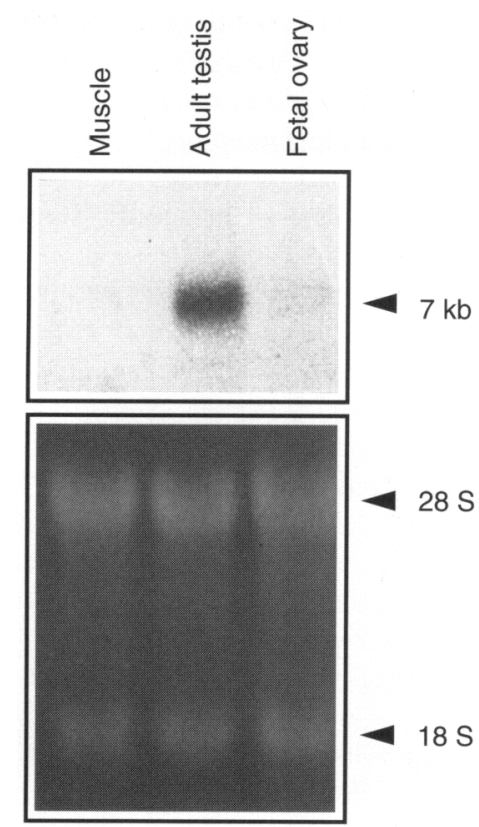

Fig. 2. Northern blot of total RNA from muscle, adult testes and fetal ovary after hybridization, with GEG-108 clone as probe. The ethidium bromide staining of the gel shows equivalent loading of the samples. A low level of transcript accumulation is observed in the fetal ovary sample compared with the adult testes.

ubiquitin (GEG-146, 159), $\alpha$-globin (GEG-70, 90, 104) and mitochondrial genome (GEG-17, 102). However, while in all redundant clones the $5^{\prime}$ ends were different, internal redundancy, as a consequence of library amplification, cannot be considered. Consequently, the multiple presence of these clones represents the relative abundance of the corresponding transcripts.

Developmental gene expression was investigated on northern blots for novel gametogenesis expressed genes. Initially, the analysis was performed on samples of testes, considering both the cumulative process of cell differentiation and the relative accessibility of testis RNA samples compared with those of fetal ovaries. In this analysis, samples of adult brain, kidney or muscle RNAs were included, together with RNA from human testes (Table 2).

For expression during testis development, different patterns of expression were observed: (i) clones, such as GEG-108, showed high expression during testicular development (Fig. 2); (ii) clones, such as GEG-123, displayed changes in the pattern of transcripts during gametogenesis, in which the main transcript accumulated during prepubertal stages, but decreased in adults, when a new transcript corresponding to $1.2 \mathrm{~Kb}$ appeared (Fig. 3); and (iii) in clones such as GEG-154, profiles of the development expression of transcripts occurring first in prepubertal testes coincidently with the onset of meiosis accumulated in later stages of development, in some cases concomitantly with the appearance of new transcripts (Fig. 4).

The specificity of expression of these fetal ovary clones in testis varied for the different novel genes. In general, coexpression was frequent in adult brain and kidney. However, in some clones, no signal was detected in somatic tissues or was barely detected in some specific somatic RNA analysed, as in
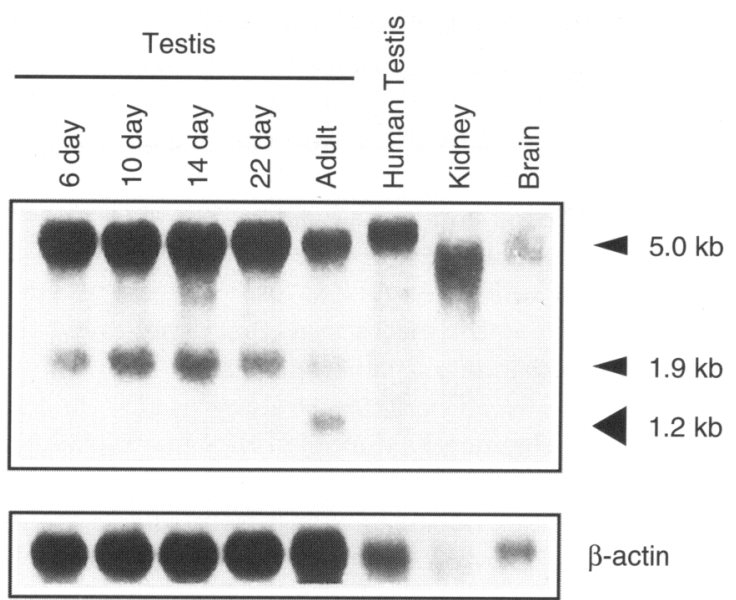

Fig. 3. Pattern of gene expression within developing mouse seminiferous epithelium, fetal somatic tissues and human testis. Northern hybridization uses a cDNA probe of clone GEG-123. Total RNA $(15 \mu \mathrm{g})$ was isolated from mouse testis for the indicated days (lanes 1-5), human adult testis (lane 6), mouse fetal kidney (lane 7) and fetal brain (lane 8). Estimated size in bases is indicated. The filters were stripped from the probe and rehybridized with a $\beta$-actin probe as control.

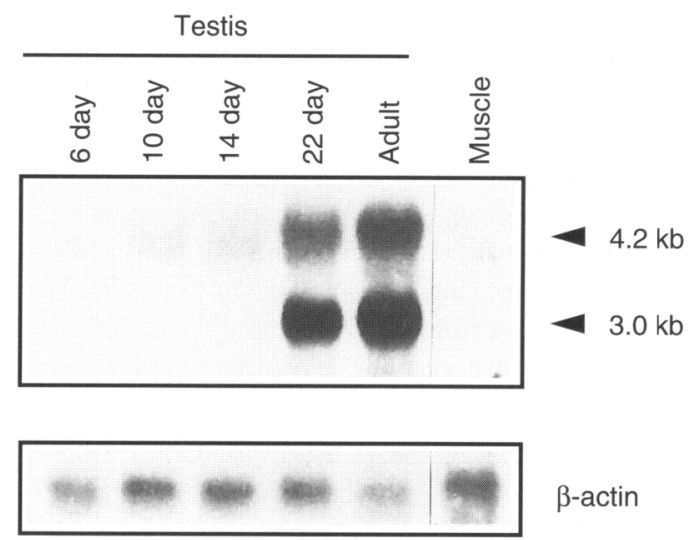

Fig. 4. Pattern of mRNA accumulation within mouse seminiferous epithelium, and somatic muscle tissue. Northern blot hybridization uses a probe of clone GEG-154 cDNA. Samples of mRNA were isolated from the ages designated in Fig. 3. The $\beta$-actin signal was obtained from stripping the filter and rehybridization with the corresponding probe.

the case of GEG-154 (Fig. 4) or GEG-108. In the case of GEG-108, fetal ovary at day 16 after coitus was also analysed, and showed a much lower expression than that detected in adult testis (Fig. 2).

Signals were also generally detected in RNA derived from human adult testis. A recurrent observation in human material was that the corresponding transcripts were slightly bigger.

\section{Discussion}

Although genes that are expressed specifically during spermatogenesis have been studied (Wolgemuth and Watrin, 
1991), genes expressed during the fetal development of oocytes have not been investigated. The development of female gametogenesis in the mammalian fetus is a singular process of differentiation starting with the fetal development of oocytes but with a programmed arrest at the dictyate stage. The terminal differentiation in adult life continues in a cyclic manner and is associated with ovulation. The analysis of the genes expressed, both in oogenesis and spermatogenesis, can help in understanding the mechanisms that genetically regulate the complex programme of gametogenesis.

In the study reported here, the strategy used to find genes expressed more abundantly during both gametogenesis processes was based on a double differential screening of fetal ovary clones by single-stranded cDNA from adult testis versus single stranded cDNA probes from a pool of somatic tissue RNAs. However, in the analysis of novel gametogenesis expressed gene clones by developmental northern blots of testes and somatic tissue samples, hybridization signals were also found in some specific somatic tissues, mainly the fetal brain. In addition, Starborg et al. (1992) reported similar gene expression in the testes and the nervous system of mice, including specific expression in both tissues of genes encoding isoenzymes of glutathione S-transferase (Campbell et al., 1990), neuropeptides (Kilpatrick and Millette, 1986; Gizang-Ginsberg and Wolgemuth, 1987; Kilpatrick et al., 1987) and growth factor (Ayer-LeLievre et al., 1988). Therefore, in this study, brain samples were included in the analysis of expression.

The results of this study indicated qualitative and quantitative differences in some specific transcripts expressed in gametic tissues and somatic tissues. Similar results were reported in studies of gene regulation during spermatogenesis. These include the use of different promoters (Howard et al., 1990), alternative splicing (Haugen et al., 1990; Foulkes et al., 1992, 1993) and alternative polyadenylation (Meijer et al., 1987). The signal observed in the northern analysis could also reflect the possible presence of gonad-specific isoforms, as demonstrated in differentiating spermatocytes (McCarrey and Thomas, 1987; Thomas et al., 1990) with specific gene regulation (Robinson et al., 1989).

A pleiotropic effect could be exhibited by some genes, affecting multiple functions of cell differentiation and development. Some clones corresponding to known genes with a defined participation in differentiation programmes could be included in this category. An abundance of ubiquitin as free protein (Agell and Mezquita, 1988) or ubiquitin-histone conjugates (Agell et al., 1983) was reported during spermatogenesis, and Loir et al. (1984) propose a putative role for these. Nevertheless, the abundance of ubiquitin during oogenesis has not been detected before. Since a relatively high proportion of different ubiquitin clones was found in our library, a transcript accumulation during fetal oogenesis similar to that observed on adult testis can be inferred. Likewise, the variant histone H3.3 could have an important function during the gametogenesis differentiation. Two different clones similar to a H3.3A pseudogene were found in the cDNA library described here. The mouse histone variant cDNA for $\mathrm{H} 3.3 \mathrm{~A}$ has not been cloned and sequenced until now. Sequencing and characterization of these clones is now in progress and a domain of the $5^{\prime}$ untranslated regions of this gene has already been found to have a high sequence homology with the $3^{\prime}$ region of a pseudogene of the $\alpha$-globin gene (D. M. López-Alañón, L. A. Lopez-Fernández, V. Castañeda, D. B. Krimer and J. del Mazo, unpublished). This could explain the presence of clones homologous to $\alpha$-globin in the library. However, a spermatidspecific histone is described by Moss et al. (1994), suggesting the synthesis of other histones at specific stages of gametogenesis.

The molecular approach presented here, based on the comparative analysis and cloning of genes expressed in female and male gametogenesis, can elucidate regulatory mechanisms involved in shared processes of differentiation such as meiosis. These studies also contribute to the analysis of developmental functions and their regulatory effect on cell systems that control the differentiation of germ cells such as Sertoli and granulosa cells. In addition, considering the complex mechanisms of gene expression required to form gamete cells, these studies provide tools of molecular analysis that have possible implications in other processes of terminal differentiation.

The novel sequences reported in this paper have been deposited in the EMBL database accession nos. X71637X71652, inclusive.

These studies were supported by grants from DGICYT (PB890053), (PB 92-0063) and CAM (C077/91).

\section{References}

Adams MD, Kelly JM, Gocayne JD, Dubnick M, Polymeropoulos MH, Xiao H, Merril CR, Wu A, Olde B, Moreno RB, Kerlavage AR, McCombie WR and Venter JC (1991) Complementary DNA sequencing: expressed sequence tags and Human Genome Project Science 252 1651-1656

Adams MD, Kerlavage AR, Fields C and Venter JV (1993) 3400 new expressed sequences tags identify diversity of transcripts in human brain Nature Genetics 4 256-267

Agell N and Mezquita C (1988) Cellular content of ubiquitin and formation of ubiquitin conjugates during chicken spermatogenesis Biochemical Journal 250 883-889

Agell N, Chiva M and Mezquita C (1983) Changes in nuclear content of protein conjugate histone $\mathrm{H} 2 \mathrm{~A}$-ubiquitin during rooster spermatogenesis Letters of the Federation of European Biochemical Societies 155 209-212

Ausubel FM, Brent R, Kingston RE, Moore DD, Seidman JG, Smith JA and Struhl K (1990) Current Protocols in Molecular Biology. Greene Publishing Associates and Wiley-Interscience, New York

Ayer-LeLievre C, Olson L, Ebendal T, Hallbook F and Persson H (1988) Nerve growth factor mRNA and protein in the testis and epididymis of the mouse and rat Proceedings National Academy of Sciences USA 85 2628-2632

Bellvé AR, Cavicchia JC, Millette CF, O'Brien DA, Bhatnagar YM and Dym M (1977) Spermatogenic cells of the prepuberal mouse: isolation and morphological characterization The Journal of Cell Biology 74 68-85

Campbell E, Takahashi Y, Abramovitz M, Peretz M and Listowsky I (1990) A distinct human testis and brain $\mu$-class glutathione S-transferase Journal Biological Chemistry 265 9188-9193

Chomczynski P and Sacchi N (1987) Single-step method of RNA isolation by acid guanidinium thiocyanate-phenol-chloroform extraction Analytical Biochemistry 162 156-159

Djakiew D and Dym M (1988) Pachytene spermatocyte proteins influence Sertoli cell function Biology of Reproduction 39 1193-1205

Eppig JJ (1991) Intercommunication between mammalian oocytes and companion somatic cells BioEssays 13 569-574

Foulkes NS, Mellstrom B, Benusiglio E and Sassonecorsi P (1992) Developmental switch of CREM - function during spermatogenesis - from antagonist to activator Nature $\mathbf{3 5 5} 80-84$

Foulkes NS, Schlotter F, Pevet P and Sassone-Corsi P (1993) Pituitary hormone FSH directs the CREM functional switch during spermatogenesis Nature $\mathbf{3 6 2}$ 264-267 
Gizang-Ginsberg E and Wolgemuth DJ (1987) Expression of the proopiomelanocortin gene is developmentally regulated and affected by germ cells in the male mouse reproductive system Proceedings National Academy of Sciences USA 84 1600-1604

Haugen T, Paulssen E, Gordeladze J and Hansson V (1990) A unique mRNA species for the $\alpha$ subunit of $G$ is present in rat haploid germ cells Biochemical and Biophysical Research Communications $16891-98$

Hecht NB (1986) Regulation of gene expression during mammalian spermatogenesis. In Experimental Approaches to Mammalian Embryonic Development pp 151-193 Eds I Rossant and RA Pedersons. Cambridge University Press, Cambridge

Höog C (1991) Isolation of a large number of novel mammalian genes by a differential cDNA library screening strategy Nucleic Acids Research 19 6123-6127

Howard T, Shai S, Langford T, Martin B and Bernstein K (1990) Transcription of testicular angiotensin-converting enzyme (ACE) is initiated within the 12th intron of the somatic ACE gene Molecular and Cellular Biology 10 4294-4302

Kierszenbaum AL and Tres LL (1974) Nucleolar and perichromosomal RNA synthesis during meiotic prophase in the mouse testis The Journal of Cell Biology 60 39-53

Kilpatrick DL and Millette CF (1986) Expression of pro-enkephalin messenger RNA by mouse spermatogenic cells Proceedings National Academy of Sciences USA 83 5015-5018

Kilpatrick DL, Borland K and Jin DF (1987) Differential expression of opioid peptide genes by testicular germ cells and somatic cells Proceedings National Academy of Sciences USA 84 5695-5699

Loir M, Caraty A, Lanneau M, Menezo Y, Muh JP and Sautiere P (1984) Purification and characterization of ubiquitin from mammalian testis Letters of the Federation of European Biochemical Societies 169 199-204

López-Fernández LA and del Mazo J (1993) Construction of subtractive cDNA libraries from limited amounts of mRNA and multiple cycles of subtraction BioTechniques 15 654-658

McCarrey JR and Thomas K (1987) Human testis-specific PCK gene lacks introns and possesses characteristics of a processed gene Nature $\mathbf{3 2 6}$ 501-505
Meijer D, Hermans A, Von Lindern M, Van Agthoven T, De Klein A, Mackenbach P, Grootegoed A, Talarico D, Della Valle G and Grosveld G (1987) Molecular characterization of the testis specific $c-a b l$ mRNA in mouse EMBO Journal $64041-4048$

Mintz B and Russell ES (1957) Gene-induced embryological modifications of primordial germ cells in the mouse Journal of Experimental Zoology 134 207-238

Moss SB, Ferry AR and Groudine M (1994) An alternative pathway of histone mRNA 3' end formation in mouse round spermatid Nucleic Acids Research 22 3160-3166

Nedivi E, Hevroni D, Naot D, Israeli D and Citri Y (1993) Numerous candidate plasticity-related genes revealed by differential cDNA cloning Nature 363 718-722

Pearson WR (1990) Rapid and sensitive sequence comparison with FASTP and FASTA Methods in Enzymology 183 63-98

Pescovitz OH, Srivastava CH, Breyer PR and Monts BA (1994) Paracrine control of spermatogenesis Trends in Endocrinology and Metabolism 5 126-13I

Robinson MO, McCarrey JR and Simon MI (1989) Transcriptional regulatory regions of testis specific PGK-2 defined in transgenic mice Proceedings National Academy of Sciences USA 86 8437-8441

Saiki RK, Scharf S, Faloona F, Mullis KB, Horn GT, Erlich HA and Arnheim N (1985) Enzymatic amplification of $\beta$-globin genomic sequences and restriction site analysis for diagnosis of sickle cell anemia Science 230 1350-1354

Sambrook J, Fritsch EF and Maniatis T (1989) Molecular Cloning: A Laboratory Manual. Cold Spring Harbor Laboratory, New York

Speed RM (1982) Meiosis in the foetal mouse ovary I. An analysis at the light microscope level using surface spreading Chromosoma 85 427-437

Starborg M, Brundell E and Höög C (1992) Analysis of the expression of a large number of novel genes isolated from mouse prepubertal testis Molecular Reproduction and Development 33 243-251

Thomas K, del Mazo J, Eversole P, Bellvé A, Hiraoka Y, Li SS-L and Simon M (1990) Developmental regulation of expression of the lactate dehydrogenase (LDH) multigene family during mouse spermatogenesis Development 109 483-493

Wolgemuth DJ and Watrin F (1991) List of cloned mouse genes with unique expression patterns during spermatogenesis Mammalian Genome 1 283-288 